\title{
Diacronie
}

Studi di Storia Contemporanea

$\mathrm{N}^{\circ} 20,4 \mid 2014$

II diritto militante

\section{Amedeo Osti Guerrazzi, The Italian Army in Slovenia. Strategies of antipartisan Repression, 1941-1943}

\section{Niall MacGalloway}

\section{Q OpenEdition}

1 Journals

\section{Electronic version}

URL: http://journals.openedition.org/diacronie/1814

DOI: 10.4000/diacronie.1814

ISSN: 2038-0925

\section{Publisher}

Association culturelle Diacronie

\section{Electronic reference}

Niall MacGalloway, « Amedeo Osti Guerrazzi, The Italian Army in Slovenia. Strategies of antipartisan Repression, 1941-1943 », Diacronie [Online], № 20, 4 | 2014, document 17, Online since 01 December 2014, connection on 24 September 2020. URL : http://journals.openedition.org/diacronie/1814 ; DOI : https://doi.org/10.4000/diacronie.1814 


\section{RECENSIONE:}

\section{Amedeo OSTI GUERRAZZI, The Italian Army in Slovenia, Strategies of antipartisan Repression, 1941-1943, New York, Palgrave Macmillan, 2013, 196 pp.}

by Niall MacGALLOWAY*

The explosion of the myth of Italiani brava gente has ushered in a host of new work on the brutality of Italian regimes throughout Europe and Africa. Marco Cuzzi, Davide Rodogno, Eric Gobetti, Giorgio Rochat, H. James Burgwyn and Angelo Del Boca have laid the foundations of work on Italian conduct prior to and during the Second World War. ${ }^{1}$ It has opened new avenues in the study of Italian history, removing a layer of protection that has prevented the Italian government and armed forces from coming under the same criticism that their German counterparts have. This shield has, in the past, obscured the views of historians wishing to conduct meaningful and comprehensive studies that have too readily brushed over the complexities of the occupied territories. These works have gradually constructed a nexus of investigations that have revealed fascinating, but sometimes difficult to accept, conclusions, particularly those who have benefitted from the aforementioned vested interest. Amedeo Osti Guerrazzi's work on anti-partisan tactics in occupied Slovenia can now join them, filling a geographical lacuna in the historiography, while providing a useful point of comparison with other territories.

1 CUZZI, Marco, L'occupazione italiana della Slovenia, 1941-1943, Roma, Stato Maggiore dell'Esercito, Ufficio Storico, 1998; RODOGNO, Davide, Fascism's European Empire, Italian Occupation during the Second World War, Cambridge, Cambridge University Press, 2006; GOBETTI, Eric, Alleati del nemico, L'occupazione italiana in Jugoslavia, Rome-Bari, Laterza, 2013; ROCHAT, Giorgio, Le guerre italiane, 1935-43: dall'impero d'Etiopia alla disfatta, Torino, Einaudi, 2005; DEL BOCA, Angelo (a cura di), I gas di Mussolini: il fascismo e la guerra d'Etiopia, Roma, Editori Riuniti, 2007. 
The central thesis of this work is clear: that Italian military action in Slovenia was not only brutal, but unnecessary and damaging to Italian-Slovenian relations for the duration of the war. On the whole, Guerrazzi is successful in showing this. The volume is divided into five chronological chapters, with a final chapter on the commemoration of Italian actions. The structure of this book is one of its main strengths in demonstrating how Italian actions became increasingly violent and callous within the zone. This is undoubtedly aided by the chronological structure, which allows the reader to see these increases as the duration of the occupation went on. Appropriate distinctions are made in the book between particular commanders, comparing and contrasting their actions, whilst analysing how far their particular methods went to shaping policies and levels of violence. Guerrazzi, however, is not content to allow the "great men" alone to shape these policies, and skilfully weaves the actions of units and individuals into this narrative.

Perhaps most importantly, Guerrazzi's work moves away from the idea that violence was restricted to unruly or psychologically imbalanced individuals, or the more excessive units such as the MVSN. In this, Guerrazzi succeeds in bringing study of the Slovenian occupation in line with work carried out by Omer Bartov and Christopher Browning, who have concluded that far from extremist minorities, killings in the German-occupied Eastern European territories were very much the work of "ordinary men". ${ }^{2}$ The idea that Italian excesses in Slovenia were brought on by "hot" violence spur of the moment killing carried out due to anger or grief at the loss of comrades - is blatantly false. Guerrazzi goes to great lengths to show that ordinary soldiers were bombarded with propaganda which de-humanised the enemy as racially inferior, easing the process of killing and mass execution. Moreover, Italian commanders went to great lengths not only to de-humanise, but to de-legitimise Slovenian partisans as "irregular combatants". This allowed their killing not only to become justified, but legal. These were important steps that were, ultimately, the culmination of a long process of de-Slavicisation in Fascist Italy. Those soldiers and units from the Venezia Giulia could be particularly brutal their actions against the Slovenians, at least partially due to the fact that they had been exposed to the greatest amount of anti-Slavic propaganda. Yet, Guerazzi also shows the convergence of politics and race during this period with great skill. Many of the Italian troops were told that they were not only fighting Slavs, but

\footnotetext{
2 BARTOV, Omer, The Eastern Front, 1941-45: German Troops and the Barbarisation of Warfare, Oxford, Palgrave, 2001; BROWNING, Christopher R., Ordinary Men, Reserve Police Battalion 101 and the Final Solution in Poland, London, HarperCollins, 1998.
} 
Communists, to the point where the two terms became practically synonymous terms in the zone.

These are not radical or new ideas within Guerazzi's study. In this sense, Guerazzi builds upon groundwork laid by other scholars, yet he augments this with his own noteworthy archival digging. Not content with resting upon the laurels of those who carried out work in the very same archives, Guerazzi has spent time examining not only the propaganda which the soldiers were fed, but the historical diaries which allow the author to analyse how it was digested. While no section makes this its distinct or sole focus, Guerazzi does examine these reactions in detail. Indeed, this forms a central part of his argument that violence against Slovenes was not "hot", but cold and calculated, even from the ordinary soldiers who carried it out. The propaganda which produced this effect was almost certainly driven from the high echelons of the Italian army. Both Roatta and Robotti pushed for harsh actions against the partisans, with the now infamous "Circular $3 \mathrm{C}$ " forming the apex of a policy which drove for increasingly bloody actions.

This increase in violence leads naturally to the final theme in Guerazzi's study that partisan war moved the war away from set pieces between armies and brought the war to Slovenia as a whole. Ljubljana is a prime example. The work skilfully shows how the city was increasingly developed as a large-scale prison or concentration camp, while uncertainty about exactly who the enemy was made Italian and Slovenian co-operation increasingly unlikely to the point of impossible. Again, this point is not a new thesis developed by Guerazzi, but it serves to cover this important aspect of partisan warfare. The study successfully shows how partisan warfare in Slovenia - and this is true of the rest of Yugoslavia and Greece, to say nothing of German occupied territories in the Soviet Union - blurred lines between combatant and non-combatant so greatly that everyone was treated as a potential combatant. The result was that the increasingly brutal treatment of combatants mentioned above was meted out to growing portions of the population. This would be one of the most salient features of warfare in the Balkans during the Second World War and one of the primary reasons why attempts to occupy and annex territories in the former Yugoslav states came to such bitter conclusions. As "Balkanisation" swelled and more and more communities were pitted against one another, the situation was exacerbated. Guerazzi makes this point with flair, emphasising its role in the conflict. As the work points out, anti-partisan warfare served only to radicalise portions of the Slovene community, whose participation in resistance in turn radicalised an already extreme set of repressive tactics. 
Perhaps the only real failing of the book is a lack of comparisons with other territories in any real sense. Prior to its annexation as part of the Kingdom of Italy, Slovenia had formed part of the former Yugoslavia. Comparisons with Italian antipartisan actions in Dalmatia and Montenegro, for example, could have provided a rounder analysis of the zone. Slovenia's status as an annexed territory, to be integrated fully as part of Italy ultimately meant that actions differed slightly in this zone to others, yet Guerazzi does not exploit this to its full advantage. The reader is kept guessing at points as to how different Italian actions in Slovenia were, or whether they formed part of a larger pattern that could be applied to the Balkans in large brush strokes. This is where studies such as Rodogno's make their most powerful points. By presenting different zones of Italian occupation side by side, the reader can examine thematic issues in the broadest sense. This, however, should not be intended as too great criticism for the book to be of any merit. Guerazzi's work was never intended to be an overarching study of Italian occupation zones as a phenomenon, yet the most successful monographs focusing on one Italian occupation in particular succeed not only by analysing the chosen territory in detail, but by making these comparisons, either implicitly or explicitly.

Despite this, Guerazzi has obviously produced a work of real quality. It should be of interest not only to those interested in Balkan or Italian history, but those interested in guerrilla warfare and responses to this style of fighting. The author not only weaves an easy to follow narrative, but highlights the key themes in an area where academics are only beginning to shine light. 


\section{* The autor}

Niall MacGalloway is PhD student at the University of St Andrews in Scotland. His thesis is entitled, The Italian Occupation of South-Eastern France, 1940-43, and his interests focus on the Second World War, Italo-French relations, and inter-war Italy and France.

URL: < http://studistorici.com/progett/autori/\#MacGalloway >

\section{Per citare questo articolo:}

MACGALLOWAY, Niall, «Recensione: Amedeo OSTI GUERRAZZI, The Italian Army in Slovenia, Strategies of antipartisan Repression, 1941-1943, New York, Palgrave Macmillan, 2013, 196 pp.», Diacronie. Studi di Storia Contemporanea : II diritto militante, 29/12/2014,

URL:< http://www.studistorici.com/2014/12/29/macgalloway_numero_20/ >

Diacronie Studi di Storia Contemporanea Of www.diacronie.it

Risorsa digitale indipendente a carattere storiografico. Uscita trimestrale.

redazione.diacronie@hotmail.it

Comitato di redazione: Jacopo Bassi - Luca Bufarale - Elisa Grandi - Deborah Paci - Fausto Pietrancosta - Matteo Tomasoni - Luca Zuccolo 